\title{
THE TONGUE IS MIGHTIER THAN THE PRINTING PRESS? REFLECTIONS ON THE PRODUCTION OF ORAL HISTORIES AND ON LANGUAGES OF LEGITIMATION
}

\author{
Benjamin ZACHARIAH
}

COBISS 1.01

\section{ABSTRACT \\ The Tongue is Mightier than the Printing Press? Reflections on the Production of Oral Histories and on Languages of Legitimation}

The article is a set of reflections on the uses of oral history in a communicative endeavour that succeeds very often in effacing the role of the interviewer even as the demands of self-reflexivity insist on centring that role. The author consider cases where there is neither a clearly defined interviewer nor interviewee, nor is there an attempt to write down experiences as history. Following this, it asks what can be told in or by oral histories when the communication that produces them seeks to recover otherwise inaccessible histories and memories, but must use languages of legitimation that often cannot speak clearly about those inaccessible histories and memories.

KEY WORDS: legitimation, writing, history, reification, collective memory

\section{IZVLEČEK}

\section{Ali je jezik močnejši od tiskane besede? Razmišljanja o produkciji ustnih zgodovin} in jezikih legitimitete

Članek prinaša nekaj razmislekov o uporabi ustne zgodovine v komunikaciji, v kateri je vloga spraševalca pogosto podcenjena, čeprav bi potreba po samorefleksiji terjala ravno nasprotno. Avtor navaja primere brez jasno opredeljenega spraševalca in intervjuvanca, kakor tudi brez zapisa dogajanja kot zgodbe. Posledično se sprašuje, kaj vse ustna zgodovina lahko sporoča, če si komunikacija, v kateri nastajajo ustni zgodovinski viri, prizadeva oživljati sicer nedostopne pripovedi in spomine, hkrati pa mora uporabljati neki jezik legitimitete, ki pa teh pogosto ni sposoben jasno izraziti. KLJUČNE BESEDE: legitimiteta, pisanje, pripoved, reifikacija, kolektivni spomin

PhD in History, Senior Research Fellow, Forschungszentrum Europa, University of Trier, Universitätsring 15, D-54296 Trier; zachariah@uni-trier.de - The author would like to thank Anna Diem, Ana Jelnikar, Lutz Raphael, Debojit Thakur, and two anonymous referees, for engaging closely with the text of this essay. 


\section{INTRODUCTION}

The trouble with oral history has been documented at length by several of its practitioners, opponents and sceptics. It is still agreed, however, that oral histories open up areas that other histories fail to reach: the tongue is more flexible than the pen or the printing press in many respects. But how can communication happen without articulation in languages that are legitimate to both speaker and listener, to interviewer and interviewee? And what if that common language cannot be found? Historians have been uncomfortable with oral history for the recovery of event-history, but many have been persuaded of the value of oral history for the recovery of subjectivities or affect. This is congruent with the cultural or civilizational hierarchy usually implied between the oral and the written; and as there has been an implied progression from the first to the second, the latter has usually been seen as a higher form of "culture", though there have also been tendencies to reverse that hierarchy. However, the former is not replaced or effaced by the latter: as Jack Goody once put it, "it is a mistake to divide 'cultures' into the oral and the written: it is rather the oral and the oral plus the written, printed, etc. This being the case, for the individual there is always the problem of the interaction between the registers and the uses, between the so-called oral and the written traditions" (Goody 1987: xii).

It is this problem of interaction, in the field of oral history, that this essay seeks to address. Much of it is concerned with the tension between two situations: the first, in which what one says about the historical work one does, in being written down, ceases to be legitimate, because it is based on the consensus, entre nous, that we as professionals know what we are doing, and that we understand and obey the standards of a self-regulating profession to which we all hold one another; however, if we write it down, it is often subject to forms of scrutiny that make it clear that as oral history it is not worth the paper it is written on. In the second situation, this seems at first glance to be the other way around: in the production of oral histories by interviewer and interviewee, the interviewee's memories become history when the interviewer writes it down, and mere memory ascends the ladder of knowledge hierarchies to legitimate history.

As they went about writing down oral accounts, "oral historians" were producing a reification of some forms of memory as history, which in their own framework as much as that of their interviewees was more legitimate than mere "memory", taking us back to Maurice Halbwachs in the 1920s, who believed that "collective memory" had to be carefully taught (Halbwachs 1992 [1925]), and to Pierre Nora in the 1980s and 1990s, where he conceded that historians were themselves "sites of memory" (Nora 1989: 7). Historians, and oral historians prominently so, were democratically inventing traditions (Hobsbawm, Ranger 1983) whose claims to validity, depth, or longevity was difficult to assess, and could be used to bolster parochial narratives of "community" (a word that occurs with alarming regularity in a number 
of oral histories written down), or to produce or disarm languages of legitimation (Skinner 1988; Zachariah 2005: 13-14; 2019: 129-148). It was clear that event-history is hard to find in oral accounts: people misremember events, and/or transpose them to times and spaces where they make more psychological sense (Portelli 1991; Polishuk 1998). It follows that there are situations in which the sitting together of interviewer and interviewee does not produce a narrative that deviates significantly from an established, conventionalised language of legitimation. By "languages of legitimation" we are referring to the need, according to the normative rules of a given communicative context, to tailor your argument to fit an available language; you could manoeuvre away from that language and innovate, but not without reference to that language, which as a result becomes a constraining as well as a legitimating frame (Skinner 1988).

Two examples that can be used to illustrate this are that of partition narratives from South Asia, and tales of academic plagiarism that academics recount to one another but do not write down, in any public sense.' In the first case, the disjuncture between the written record and oral histories is often stark; but there is an almost Stakhanovite desire to produce more oral histories, as museums, universities and hordes of researchers vie with each other in a scramble for the memories of those about to die. In the case of academic plagiarism, the proliferation of narratives among professionals in the field, to the occasional horror of non-academics who overhear these discussions, is not matched at all by a serious public debate on the matter; and indeed, no attempt to write down oral histories of plagiarism, given that it is far from rare, can proceed without a delegitimation of the profession.

I started thinking seriously about this subject after a series of discussions that began with my being invited to speak in Ljubljana on the possibilities and limitations of oral history as part of a project called "Slovene Women Missionaries in India: A Forgotten Chapter in Intercultural Relations". This involved tracing the life stories of twelve Slovene nuns (all but one of whom are dead), who had gone to India in the course of the 20th century. The project relies heavily on doing oral history, and much of this is second-"generation" testimony, given the death of the original protagonists. The questions of how their stories are told, which are raised in other essays of the special issue of this journal, must take into account the tensions between a (theological?) language of legitimacy that befits the needs and imperatives of the Catholic Church and the orders of which they were a part; but their ability to tell their stories at all requires an ability to deviate from or manoeuvre within that language of legitimacy; and also to find a communicative register in which to speak to those who are not a part of that language community. My essay here is a response, with different material, to what I regard as analogous problems.

1 Traces might of course be found in traditional written sources as historians write notes or letters to one another, or increasingly in emails or posts on social media. 
I should include a caveat here. As with so many "theoretical" or "(self-)reflexive" essays that claim to address disciplinary problems, this too is an essay by a non-practitioner of the craft that the author claims to assess: my attempts at oral history have been colossal failures. ${ }^{2}$ And so it goes that failures turn into methodological reflections.

\section{ORAL HISTORY: THE (WRITTEN) STORY SO FAR}

Historians like their evidence to be dead. Dead people don't talk back. And you can fix what they say in terms of something that has already left a written trace, knowing full well that the written trace is a very small part of the theoretical set of things that "happened". Anthropologists, on the other hand, so they say (or so I have gathered in some conversations I've had with anthropologists), live with live people, and write about people's "life worlds", with a methodology that seems to rely on "somebody told me", tempered by "I was there for long enough to know" (which is an interesting comparison to the historians' "it's more complicated than that", followed by silence as you await an explanation). Since these conversations were not written down, once can of course ask me "How do you know you actually had this conversation?" and I can say "I can't tell you but actually I did", or that I have a few notes and a diary saying that I had that conversation, but I could have made that up as well. Oral history is not very different from the anthropologists' "somebody told me", and without the tempering factor of a long presence, because it is usually in retrospect, about events that happened "in the past" (how long ago is the past?), and (more so) about latter-day processing of those events: most oral historians would not be looking for event-history in their work. All of this is of course not always borne out by the written accounts of what anthropologists say they do, or what oral historians say they do, after they have been allowed to clean up the glitches and present their work as "wissenschaftlich". And then, of course, it takes you to the fact that any kind of encounter between two human beings being communicative is not about what actually happened in the past or present, but about how two people are trying to manoeuvre each other into a context where they get something out of each other in the present, and governed by relatively non-methodological concerns such as whether they like or dislike one another (Yow 1997).

If we look at this from our current standpoint, after what we might consider the postmodern and postcolonial diversion where we as historians were interested in subjectivities but at the same time interested in judging these subjectivities against

2 My favourite instance of this was when, during a project on how "development" was understood in the 1930s and '40s, I was disturbed that my interviewee appeared to be reproducing Ashis Nandyisms from the 1980s, which would hardly have been available to him as a young man, and which by now most people outside those in the wave so named will no longer recognise. When he started a sentence with "as my friend Ashis Nandy said ...", I was of course able to reposition the interview as part of the 1980s post/antidevelopmental moment (Benjamin Zachariah, interview with anonymised respondent, Delhi, November 1996). 
some kind of nonhistorical or superhistorical norm (the "enormous condescension of posterity", in E. P. Thompson's famous phrase) (E. P. Thompson 1963: 12), there was the problem of readings of history beyond and outside the context that was available to historical players in their own times. In some ways, oral historians are doing exactly that: they are dealing with people's memories after the event, several years down the line where the framing of the material is very different, and the original "trace", not stabilised by being written down in its own time, cannot be separated from the framing.

It was of course once assumed, and still mostly is, that oral histories were important because they were more "democratic" (Anderson et al. 1987; Perks, Thomson 1998; Abrams 2010; Perks, Thomson 2015; Yow 2015; Thompson 2017). "[T]he richest possibilities for oral history lie within the development of a more socially conscious and democratic history", Paul Thompson wrote in The Voice of the Past in 1978, a text that has become, in successive editions, the standard handbook or gospel, depending on one's preferred metaphor, for oral histories and oral historians (Thompson 1978, reprinted in Thompson 2000: viii). (It was not before the $3^{\text {rd }}$ edition that Thompson's Voices offered a definition of oral history, not his own, but that of the New Shorter Oxford English Dictionary from the 1990s: "tape-recorded historical information drawn from the speaker's personal knowledge; the use or interpretation of this as an academic subject": P. Thompson 2000:xi). Oral history provided interviewer and interviewee with the ability to co-author the histories of which they were a part; indeed, this could be the living embodiment of the meanings of "history" as both past-ness and the processing and making sense of the past in the present. Could it then be said that oral history was a communicative endeavour that succeeded very often in effacing the role of the interviewer even as the demands of self-reflexivity insist on centring that role? The co-authorship idea, of course, still implicitly assumed the primacy of interviewer over interviewee, for who would expect an ordinary person with memories to record to seek out an interviewer in order to record his or her memories as history? There was also more than a hint of social engineering implied in the selection of subject. "As oral historians, we need to develop techniques that will encourage women to say the unsaid" (Anderson et al. 1987: 104). The desire that history be relevant and "public", and indeed accessible to its protagonists, was also to lead to an insistence that professionals had no particular insight into history that was qualitatively better by any standards than the public understanding of history. And ironically, it was a Raphael Samuel from the Communist Party of Great Britain's renowned Historians Group rather than a right-wing populist who paved the way to "heritage" being reclaimed as public history (Samuel 1994, 1998; Scott Brown 2017).

The harmonious development of non-antagonistic and co-existing forms of oral history was usually assumed by its practitioners, though sometimes not: indeed, the $3^{\text {rd }}$ edition of Voices notes "the potential seeds for sectarian fragmentations", in part already reflected in a diversification of the terminology of oral history practices; but this acknowledgment appears only in the preface, which glosses over 
it quickly (P. Thompson 2000: xii). (A West German tradition of oral history that did not assume a non-confrontational and shared language of legitimation between interviewer and interviewee, dealing with the Nazi past or denazification, existed, for instance, even as West German historians acknowledged the influence of American models of oral history: for a retrospective account see Niethammer 2017.) Strangely enough, the idea that conflictual situations produce oral histories that are not necessarily celebratory or "self'-making and indeed can exacerbate memories of trauma and vulnerability or generate tragedy by making interviewees vulnerable to retribution or retaliation, and that the oral historian had a responsibility to do no harm, was a long time in becoming the profession's common sense" (Yow 1995; A. Thomson 2007). This was to some extent an "insight" intensified by the Yugoslav wars of succession and secession, and the Rwandan massacres (Jessee 2011), even as "trauma" entered a burgeoning field of "memory studies", mostly as an offshoot of studies of the massacres of European Jewry during the Second World War, and the idea of a trauma that passed (via "collective memory"?) to the next generation and beyond (La Capra 1999, 2001).

\section{PARTITION NARRATIVES FROM SOUTH ASIA}

Oral histories of the Partition of India fit very well into the themes of democratisation and of trauma. When these oral histories made their appearance, readers had been acclimatised to treating the event-history of Partition in terms of an archival narrative of political negotiations of a "transfer of power" on the one hand, and a "communal war of succession" on the other; and connections between even those two narratives were difficult to establish (Asim Roy 1990; Zachariah 2004: 120-138; Dwaipayan Sen 2012). A dark counterpoint to these historical narratives had always existed: eyewitness accounts published as first-person and sometimes autobiographical narratives (Khosla 1949; Moon 1962) or fictionalised studies of the horrors (Raza 1994 [1967]; Sahni 2001 [1974]; Manto 2014 [c. 1947]). The difficulties with first-person accounts are those of verifiability, of course; and the incomprehension with which contemporaries encountered the events as they happened of course made it particularly important to process the experiences and to give them some meaning in retrospect. Perhaps Manto's relentless and brutal telling of small anecdotes drawn from the wider carnage was one way to make sense of brutality by recounting it in its utter banality, like the story of a Sikh man's frustrated love for a Jewish woman in Karachi, her attempt to help him find and rescue the object of his current affections, and her consequent death: the story is told in a manner in which characters live amidst impending death without taking their own likely death too seriously (Manto 2014 [c. 1947]: 58-72).

If we, on the other hand, want to follow the proliferation of stories about partition that are narrated in (written) collections of interviews (which makes them different 
from what is retold in memoirs, but exactly why is probably an interesting question, taking into account the different communicative contexts), framed by the expectations of affect, we might consider that they are often lies; and probably often deliberate ones as well. Told by interviewees to interviewers in different socio-political contexts, where the demands and expectations of each are shifting, this is where it is possible, and imperative, to observe that idioms of expression conform to languages of legitimation; and when that language of legitimation is uncertain, interviewer and interviewee play out a guessing game where they fluctuate among different such languages. But there are not only lies to be had of these situations: lies emerge when it becomes impossible to acknowledge a difficult transgression, for instance that the interviewee was a member of a paramilitary organisation that conducted organised killing and looting of property, and was involved in ethnic cleansing (a retrospective term but one that was already in use by the 1990s when the interviewing wave began); the presence of "abducted women" in one's family. Equally, interviews often broke such silences, for instance in the case of the "abducted", who were often women who were forcibly removed from their families and claimed as property by members of another "community", but were also sometimes women who made active choices for practical or affective reasons to live with a man, but (even when they lived according to the new religions) were often considered implicit outsiders (again, this is sometimes better captured in fiction: see Sidhwa 1988). The "abducted women" were a question of the national honour of two new states and were treated as such (Menon, Bhasin 1998); what they might have wanted was less important, and "rescuing" abducted women by tearing them away from their new circumstances to "return" them to their communities and the states that claimed those communities was one way of ensuring a miserable and stigmatised life afterwards. These stories are recounted, but the overall narrative gravitates back to one of a temporary madness that afflicted everyone, which sits rather badly with another narrative that also makes its appearance: that of the impossibility of forgiving "them" for what they have done to "us", or equally, that "they" have now been forgiven by "us": reconciliation and forgiveness stories also make good affective material.

Given that potential to read the fluctuations in legitimating languages, it is peculiar that the difficulties with these accounts largely do not emerge as points of discussion among oral historians/ interviewers to the extent that they ought: for instance, one very well-known collection of accounts of partition experiences was published after 1992, a landmark date in the history of the legitimating vocabularies of South Asia; and the interviews were done on either side of that date. But the accounts produced take no account of this (Butalia 1998). 1992 was the date of the mobilisation of self-proclaimed "Hindu" mobs by the fascist party that as I write is in government in India, the Bharatiya Janata Party, to destroy a $16^{\text {th }}$ century mosque in Ayodhya. The subsequent breakdown of an old language of legitimacy is of interest: suddenly, the presence of Hindu sectarians and the legitimacy of openly anti-Muslim sentiments was palpable (see Ludden 1996). Butalia foregrounds the anti-Sikh 
pogroms in Delhi in 1984 in the aftermath of the assassination of Indira Gandhi by her Sikh bodyguards, itself a response to her ordering the army into the Golden Temple in Amritsar in pursuit of "militants"; and goes on to place the Ayodhya demolitions and accompanying and subsequent violence in the same continuum; but she comments not on the changes to ways of speaking legitimately about intercommunal relations, saying instead that Partition "could not so easily be put away" and it "lived on in so many people's lives" (Butalia 1998: 6-7).

Many stories are nonetheless told in whispers, and never written down. A Sikh family in which an uncle's wife, as she got older, expressed a desire to be buried: never, of course, acknowledged by the rest of the family. However loudly and publicly she said it, this was considered an eccentricity of old age. She was of course cremated when she died, but some younger members of the family had figured something out: "It was only then that we started thinking, she must have been one of the abducted women." ${ }^{13}$ Fictional accounts are often able to be more direct: Manto's short stories are clear that the narrative about partition that one hears from "Zeitzeugen" - witnesses to the time - are not accurate. "We all went mad", is the oral history narrative - epitomised and backed up by the (written) history of Gandhi as Lord Mountbatten's "one-man boundary force" in 1947, and the story of his securing from communities (by which is meant their leaders) a semblance of peace at Noakhali after the riots there in October 1946. But Noakhali was when Gandhi came after the violence had subsided: the local political influencer Golam Sarwar Hosain had had his revenge on the Roy family, and remorse could now be shown, often by people who were not directly involved in the violence but took it upon themselves to be remorseful on behalf of their "community" (S. Roy 1999). In Manto's world, armed bands of men looted property, raped women and murdered everyone they could - and the motives were not community honour, but much baser instincts were at play. And this is more in consonance with what we know from archival research: local goondas and organised paramilitary gangs had been operating for years under the patronage of every political party and faction, and their moment had finally come (Maclean, Zachariah 2019).

Still, it has become something of an industry to collect narratives of partition among "oral historians". In a car park in Lucknow, the former capital of Awadh, a city of romantic legends and culinary fantasies, I once sat in on a conference call among people working on the partition of Partition narratives, which appears to be a prominent candidate for the dominant oral history project of our times; and I had an all-too-expensive coffee at Khan Market with the person widely seen as the mastermind of the project, a former physicist whose Indian (Punjabi) roots contributed to her interest in the project. ${ }^{4} \mathrm{~A}$ hundred-odd people, it can be crudely estimated (or the estimate, being from among those working in the project, might be an overestimate), in three South Asian countries, had been engaged in conducting interviews

3 Zachariah and anonymised colleague, conversation on a bridge in Zürich, Switzerland, 2014. 
with old people who were, seventy years after the event, close to dying, or so it was thought. What ensued was described by one former interviewer as a "grab-a-granny" (in Bengali, didima-thakumader dhoro) model, though she clarified that the guidelines they had been given were to be found on the website of the (US-based) Oral History Association - and added that these were not always suitable to follow in Indian conditions. ${ }^{5}$ The interviews were to be handed over to the organisers of the project and housed at UC Berkeley (since then, the custodian of interviews has become Stanford University, reflecting a Bay Area dispute that will one day perhaps be relevant to the story); and a parallel project at Harvard, funded by a steel dynasty and coordinated by the Business School, ${ }^{6}$ and the Bay Area project ${ }^{7}$ traded a few charges about each having plagiarised the other's (reasonably obvious) idea. Meanwhile, student "assistants" in the process of completing MAs or MPhils in history or related social science subjects, and some practicing professional academics, were persuaded to take on the job of conducting interviews; students were paid, which was an improvement on conditions of unemployment and living at home supported by parents; but they were underpaid and were soon frustrated. They were told they couldn't use their own findings, which had to be handed over to the US institutions involved. Numbers and targets were handed out, in what might have been Stakhanovism or capitalist overproduction, depending on contexts and circumstances. ${ }^{8}$

Such is the case of the industrial production of oral histories: to what end? Do we know? Does anyone know? It has become customary for some years to build "alternative" or private archives, again in the interests of "decentring" or "democratising" existing narratives, or to "represent" the unrepresented (Zachariah 2019: 149-162); and that seems to be what is happening in the case of partition. Partition interviews will have their place in this archiving process, a process that now also includes the Amritsar-based Partition Museum ${ }^{9}$ - and we could also compare the oral history narratives of 1971 in the Bangladesh Liberation War Museum, whose protagonists have a longer time to live, we can assume. ${ }^{10}$ Do we, however, have an alternative narrative of legitimacy building up from this? And do the narratives produced in these oral histories break the existing language of legitimacy down? Probably not: "I asked him if I could write down what he had said, he said, 'Of course, write what you like. My life cannot get any worse.' But my own feeling is that he wasn't really aware of the kinds of implications this could have. So I did what I thought I had to: silenced those parts that needed to be kept silent" (Butalia 1998: 29).

5 https://www.oralhistory.org/about/principles-and-practices-revised-2009/ (24. 4. 2019).

6 https://mittalsouthasiainstitute.harvard.edu/oral-histories-project/ (24. 4. 2019).

7 https://in.1947partitionarchive.org/and https://exhibits.stanford.edu/1947-partition (24. 4. 2019).

8 Zachariah, interviews with several former students, whose anonymity must be respected: March-April 2019.

9 http://www.partitionmuseum.org/about-us/ and http://www.partitionmuseum.org/oral-history/ (24. 4. 2019).

10 http://www.liberationwarmuseumbd.org/oral-history/ (20. 5. 2019). 
There is the comparable case of holocaust survivor narratives (Bernard Donals, Glejzer 2000), often invoked by historians of partition, on which, it is often claimed, partition interviews ought to be based, though in the former case the victim-perpetrator categories are also externally clearer than they are in the case of partition, where oral histories have recorded the widespread intra-"community" violence of women being murdered by men lest they fall into the hands of other "communities", whose actions would violate the honour of the community (rather than in the first instance be acts of violence against the women) (Menon, Bhasin 1998). "Truth" in a literal sense is subordinate here to the psychological truths that are supposed to be brought into being by creating an oral history interviews archive. On the other hand, we have had a few cases now of Holocaust survivor narratives that have been widely acclaimed for their authenticity, before being "outed" as fictionalised accounts and their authors widely reviled (e.g. Wilkormiski 1995; Defonseca 1997).1" "Testimony" and "witnessing" are therefore things that require the authenticity of having been in the first-person position as Zeitzeuge, and no matter how well a fictionalised account fills this capacity, we do not regard it as fulfilling the same function (Preusser 2004). Why this should still be the case in a poststructural world, in oral history-writing where event-history is not sought after, and when so many memoirs or interviews are known to be products of self-censorship, selective remembering, transposed memory or deliberate lies in the sense of a conscious fabrication of what one knows or can be shown to have already known in another context, can perhaps only be explained by the superior legitimating capacity of "history" as opposed to "memory". But it is the writing down of memories as history that produces that capacity.

\section{PLAGIARISM NARRATIVES FROM ACADEMIA}

What, then, if the narratives that everyone knows cannot be written down? Perhaps there are reasons for which - like the act of censorship performed by the oral historian on behalf of her interviewee - it is safer, or more legitimate, or at any rate less delegitimating not to write down what everyone in a given in-group knows. Since much oral history-writing relies on trusting the historian and her informants, perhaps a good example of oral testimony that is not written down and is therefore not history (and for that reason not legitimate?) is the plagiarism narrative. If you write it down, and especially if you try to attribute plagiarism to someone in particular, what happens then? At its worst, it becomes considered a personal score-settling, or complaining, which is never legitimate; this is especially the case when the one trying to record the instance is the plagiarisee. The truth-value of these statements often resolves into the question of the individual guilt or innocence of named people; but since these accounts are by definition not legitimate (they are seldom, if ever, written

11 https://www.nytimes.com/2008/12/29/books/29hoax.html (29. 4. 2019). 
down, and if they are, they are seen as exceptions, which everyone within the profession knows is not the case), plagiarism as an endemic problem in academic life is not history; it is an open secret.

Here we might linger on whether such a thing as an 'open secret' deserves a place in a historian's "regime of truth", to borrow a Foucauldian phrase (Foucault 1980). Could we perhaps come up with indicative accounts, intending to highlight the systemic problems that beset an academic discipline, or perhaps all academic disciplines? There would be no attempt then to establish individual guilt; and indeed, unless one could do that according to a more rigorous legal regime of truth, "beyond a reasonable doubt" or "on balance of probability", it would be impossible to do so. Instead, the point would be to demonstrate that the nature of a self-sustaining system in which standards are set, judged and renewed by one's peers within a profession (and it might also be remembered here that a "profession" is based on professing an oath to uphold certain standards) is fatally compromised if those standards are abandoned. As for the individual tales, here again, the standards expected of oral testimony - that one knows first-hand what one narrates - would need to be the standard. According to conventions of "narrativity", as postulated by Hayden White (White 1980), there is no reason to take truth-claims in history seriously; they belong to what makes the genre. In that case, and especially in the hands of the self-confessed subjective and affective needs of the oral tradition (whether written down or not), the value of a plagiarism narrative might mainly be for an aggrieved party to "get it off her chest"; the claim might not be anything that can plausibly be intersubjectively established. Or it could indeed be that; and that might, in effect, be worse; because the plagiarist might take revenge on the plagiarisee, who is usually (though not always) the weaker party. And what if we did indeed make the narratives up? Or produce psychologically or sociologically analogous fictions that displace the actual details in order to make the generic point that there is a systemic problem in academia, but that we are not interested in the taking down of individuals?

Following are two accounts, the first, told in the first person, the second in the third. In both cases, a modicum of caution has been followed in order to make the general point and protect the identities of the persons concerned, until such time as, in the interests of a legal regime of truth, they can be brought into the open. The narrative voices differ in the interests of illustrating the different registers that are produced by first and third person accounts; it should not be taken to mean that the ' $I$ ' here refers to the current author; nor should it be taken not to mean that it does not. In a similar vein, pronouns might not refer to the actual genders of the persons concerned, nor initials their actual names. Or they might. "Oh yes, D----- stole your MPhil, didn't he?" I was greeted at a conference by this casual statement by a colleague; and I was taken aback, because I of course had not failed to notice this theft, but I did not believe that anyone else knew. I had not told a great many people, because I didn't think I'd have been believed: D----- was at the time a senior academic who had not been discredited by the effects of drink and gambling, and had had privileged 
access to an unpublished piece of work (he'd been its examiner). But the colleague worked at the same university D----- then worked at, and (I had forgotten this) pointed out to me that she had asked me for a copy of the MPhil so that she could teach it in her course. Therefore, when D---- published his article with more than a few bits from my MPhil in it, his colleagues and students at the university knew where he'd got the bits from - they said nothing, of course, because this was the "open secret" model - "everyone knows" but "we don't talk about it".

The second account is as follows. The historian B----- texted a colleague, O-----, after an article appeared with the exact same theme and extremely similar contents to a book O----- had recently published. She responded to B quite quickly: the article had come to her for review from an important journal, she'd reviewed it and suggested that it was not original (and she had said why it wasn't). It was duly rejected, then sent to another journal in another country by the author, S----, which journal also sent it to her to review. She had responded to them that she'd already rejected it for another journal, and told them the reasons. The second journal published the article, probably after it had been duly sent for peer review to other reviewers. But O----- didn't want to follow this up and make a plagiarism charge: S----- was an important professor in his own backyard (in a third country), and she might, she said, want to work in the country where he worked one day, in which case it was better to let it pass, and to rely on a public who, like B----, might have read O----'s original work, and would know that S----- had lifted O-----'s work but would, unlike B-----, but like everyone else, show sympathy to $\mathrm{O}-----$ and continue to let $\mathrm{S}-----$ pretend in public that he was an honourable historian.

The open secret would have to work in her favour; and if it did not, the plagiarist would have done no more damage than plagiarised a piece of work that - at least in this case - had already escaped into the public domain before the plagiarist realised that his plagiarism was too late. But an open secret works by being something no one really wants to talk about or to make an issue of: it might in some circles be the source of sympathy for someone seen as hard done by, but its existence is part of a larger power game that survives because no one talks about it in legitimating or delegitimating terms - and a cursory glance at the uses of this term for systematic study of a socially or historically relevant issue would create a list that includes the functioning of the secret services in Britain (Rimmington 2001), illegal detention and torture in Uganda (Human Rights Watch 2009), abortion in Burkina Faso (Rossier 2007), domestic violence in Ghana (Cantalupo et al. 2006), or literary fiction in which "nothing happens", "where the term open secret refers to non-emphatic revelation - revelation without insistence and without rhetorical underscoring ... a gift that does not demand response but is there for the having, as readily taken up as it is set aside" (François 2008: xv-xvi), child sexual abuse in the Californian film industry, appropriately enough presented in a documentary film (Berg 2014), and the sexual torture of men in conflict situations (Oosterhoff et al. 2004). What happens when an "open secret" is written down, systematically studied, and thereby sought to be delegitimised? 
It might be noted that the "open secret" model here relates to more than the question of plagiarism. A colleague noted that the best-known bibliography in his field lists only publications of authors in or from "western" universities (their own classification), which makes little sense as a principle of selection, given that the field of history he works in is concerned with an area with a rich and voluminous tradition of history-writing, albeit in a non-European language; and writing in that language only appears in the bibliography if it is produced by a scholar working in the "west". The corollary to this is that the area that the writing cited in the bibliography is concerned with is written about from the "west"; scholars writing in that area are not cited, in the bibliography or by scholars who can read the language well enough to use it in their research - and yet not cite scholars working in that language from the region. ${ }^{12}$ This asymmetry of citation - alongside the problem of communities of collusive citation - is often part of the oral communication among a scholarly community of researchers; and the open secret functions as (de)legitimator without being written down.

\section{NOTES IN LIEU OF CONCLUSIONS}

Since in the last decades, historical accounts have been compared to fiction, and merely an attempt at realism in a literary sense rather than at recording reality in terms of Wissenschaft has been attributed to them, the once-felt need to hold the line between "hard" archival sources and "soft" oral testimony has weakened. After all, what are "archival" sources but (oral?) testimony written down in the past rather than in the present? And the power/knowledge critiques of archives as repositories of the records of domination, combined with attempts to create non-"elite" archives, could be said to be doing similar work to that which oral histories, in different communicative contexts, do.

The problem in all historical reconstruction remains, however, the question of verifiability, and the standards of that verifiability. In legal testimony, the role of eyewitnesses has long been crucial, but they are held to more rigorous standards of truth than are Zeitzeugen, contemporary witnesses, in the field of history - and the process is far more confrontational. In theory, of course, the oral history interview situation can be one in which interviewer and interviewee confront one another as across the barriers of the witness-box; but the communicative context can vanish quite easily if this begins to happen. And so it is that in order to keep harmonious communicative contexts functioning, difficult questions that border on interrogation do not get asked; unless of course either party is willing to discontinue the communication.

What is clear in written as well as oral testimonies is that there is a grammar of legitimacy that is not broken down unless one party is willing to challenge them.

12 Zachariah, conversations with anonymised colleague, spring, 2019. 
"In the case of both written and oral testimonies, in spite of the prima facie differences between them, it becomes clear that the distance between what has been witnessed and what can be committed to testimony - what was seen and what can be said - is often wide, but always palpable" (Bernard Donals, Glejzer 2000: 2). Nevertheless, oral testimonies are legitimised by being written down as history; this is something that has long been known, and even desired by the "democratisers". But as the oral historians of earlier generations were vulnerable to the charge that they were creating "feelgood histories" by bringing to the fore the "marginalised and unspoken" experiences of groups that had been hidden from history or underrepresented more generally - in oral histories, histories "from below" and/or other democratising and decentralising impulses in historiographical production - it is time to prepare the counter-charge that the expansion in productions of oral histories and subjectivities can bolster ethnic, ethnocentric, exclusionary and divisive narratives, reifying "from below" what might well not be incompatible with exclusionary practices "from above".

The subjective and affective role of many oral histories might take us in the direction of reading them like psychoanalytic case histories: they are therapeutic accounts mediated by the therapist and purporting to record, with necessary redactions, the social and psychological predicament of the interviewee-patient-client (as terminology shifts in both professions). In this context, the faking of memoirs and the misremembering of memory are not too far away from each other. The question is whether oral historians wish to hold this line or not. Writing in a contextualising piece on the phenomenon of the fake Holocaust memoir, in which an author "feels" like a Holocaust survivor, even if this can be palpably shown to be factually wrong, Frank Furedi commented:

... it is important to realise that contemporary culture provides a powerful incentive to individuals to manipulate their memory and present themselves as traumatised victims. The assertion of trauma as a result of past suffering has become a way of winning public recognition and attention, and of making a claim on resources. Increasingly, the act of remembering has been turned into a public performance ... In the current cultural climate, it is inevitable that abuse memoirs have a tendency to stretch the boundary between fact and fiction. Readers and critics usually feel awkward and inhibited about questioning the veracity of such memoirs. Scepticism is discouraged in an era built upon the therapeutic ethos. "Believe the child", "Believe the patient", "Believe the abused" - today, such invocations are used to sacralise the claims of victims. (Furedi 2008)

It is all too easy, then, for an interviewer to be manipulated, not necessarily consciously, by an interviewee into accepting stories that might make psychological sense - perhaps in the manner of the recounting of collective memory, which is of course taught and not "remembered" first-person memory - and because the language of 
legitimation allows the story to make sense, whether "true" or not. These are not hard lines; and it is hard to draw them at all without countervailing sources to check.

Perhaps the counter-example of that which functions without being written down needs to be looked at in more detail: why do we not write them down? Which ones do we choose to write down? Can one historicise the open secret? And in bringing to a wider "public" the internal "open secrets" of smaller groups - for whom the open secret, for good or ill, has been a modus vivendi that allows them to operate despite, parallel to, or behind, existing languages of legitimacy that would otherwise obstruct them, does the (oral) historian provide a worthwhile addition to matters of public consciousness?

\section{REFERENCES}

Abrams, Lynn (2010). Oral History Theory. London: Routledge.

Anderson, Kathryn, Armitage, Susan, Jack, Dana, Wittner, Judith (1987). Beginning Where we are: Feminist Methodology in Oral History. The Oral History Review 15/1, 103-127.

Berg, Amy J. (2014). An Open Secret [documentary film]. New York: DOC NYC festival. Bernard Donals, Michael, Glejzer, Richard (2000). Between Witness and Testimony: Survivor Narratives and the Shoah. College Literature 27/2, 1-20.

Butalia, Urvashi (1998). The Other Side of Silence: Voices from the Partition of India. Delhi: Viking.

Cantalupo, Nancy Chi, Vollendorf, Lisa, Kay Pak, Martin, Shin, Sue (2006). Domestic Violence in Ghana: The Open Secret. Georgetown Journal of Gender and the Law 7, 531-597.

Defonseca, Misha (1997). Misha: A Memoir of the Holocaust Years. Gloucester, MA: Mt Ivy Press.

Foucault, Michel (1980). Truth and Power. Power/Knowledge: Selected Interviews and Other Writings 1972-1977 (ed. Colin Gordon). New York: Harvester, 109-133.

François, Anne-Lise (2008). Open Secrets: The Literature of Uncounted Experience Stanford: Stanford University Press.

Furedi, Frank (2008). 'History-as-Therapy', https://www.spiked-online.com/2008/03/05/ history-as-therapy/ (1. 5. 2019).

Goody, Jack (1987). The Interface Between the Written and the Oral. Cambridge: Cambridge University Press.

Halbwachs, Maurice (1992) [1925]. On Collective Memory (new edition). Chicago: Chicago University Press.

Hobsbawm, Erick John, Ranger, Terence (eds.) (1983). The Invention of Tradition. Cambridge: Cambridge University Press.

Human Rights Watch (2009). Open Secret: Illegal Detention and Torture by the Joint Anti-Terrorism Task Force in Uganda. New York etc: Human Rights Watch. 
Jessee, Erin (2011). The Limits of Oral History: Ethics and Methodology Amid Highly Politicized Research Settings. Oral History Review 38/2, 287-307.

Khosla, Gopal Das (1949). Stern Reckoning. Delhi: Bhawnani.

La Capra, Dominick (1999). Trauma, Absence, Loss. Critical Inquiry 25/4, 696-727.

La Capra, Dominick (2001). Writing History, Writing Trauma. Baltimore: Johns Hopkins University Press.

Ludden, David (ed.) (1996). Making India Hindu: Religion, Community and the Politics of Democracy in India. Delhi: Oxford University Press.

Maclean, Kama, Zachariah, Benjamin (2019). Violence, Non-Violence, the State and the Nation: India, 1858-1958. The Cambridge World History of Violence (ed. Philip Dwyer). Cambridge: Cambridge University Press (forthcoming).

Manto, Saadat Hasan (2014) [c. 1947]. Mottled Dawn. London: Penguin.

Menon, Ritu, Bhasin, Kamala (1998). Borders and Boundaries: Women in India's Partition. New Delhi: Kali for Women.

Moon, Penderel (1962). Divide and Quit. Berkeley: University of California Press.

Niethammer, Lutz (2017), im Gespräch mit Veronika Settele und Paul Nolte. Oral History in der deutschen Zeitgeschichte. Geschichte und Gesellschaft 43, 110-145.

Nora, Pierre (1992). Between Memory and History. Les Lieux de Memoire, Representations 26, 7-24.

Oosterhoff, Pauline, Zwanikken, Prisca, Ketting, Evert (2004). Sexual Torture of Men in Croatia and Other Conflict Situations: An Open Secret. Reproductive Health Matters 12/23, 68-77.

Perks, Robert, Thomson, Alistair (2015). The Oral History Reader (3 ${ }^{\text {rd }}$ edn). London: Routledge.

Perks, Robert, Thomson, Alistair (eds.) (1998). The Oral History Reader. London: Routledge.

Polishuk, Sandy (1998). Secrets, Lies, and Misremembering: The Perils of Oral History Interviewing. Frontiers: A Journal of Women Studies 19/3, 14-23.

Portelli, Alessandro (1991). The Death of Luigi Trastulli and Other Stories: Form and Meaning in Oral History. Albany, N.Y.: State University of New York Press.

Preusser, Heinz-Peter (2004). Erinnerung, Fiktion und Geschichte: Über die Transformation des Erlebten ins kulturelle Gedächnis: Walser-Wilkomirski-Grass. German Life and Letters 57/4, 488-503.

Raza, Rahi Masoom (1994) [1967]. The Feuding Families of Village Gangauli [Adha Gaon]. Delhi: Penguin.

Rimmington, Stella (2001). Open Secret: The Autobiography of the Former Director-General of MI5. London: Hutchinson.

Rossier, Clémentine (2007). Abortion: An Open Secret? Abortion and Social Network Involvement in Burkina Faso. Reproductive Health Matters 15/30: 230-238.

Roy, Asim (1990). The High Politics of India's Partition: The Revisionist Perspective. Modern Asian Studies 24/2, 385-415. 
Roy, Sulagna (1999). Communal Conflict in Bengal, 1930-1947 (unpublished Phd dissertation). University of Cambridge.

Sahni, Bhisham (2001) [1974]. Tamas. Delhi: Penguin.

Samuel, Raphael (1994). Theatres of Memory: Past and Present in Contemporary Culture. London: Verso.

Samuel, Raphael (1998). Theatres of Memory, vol. 2: Island Stories: Unravelling Britain. New York: Verso.

Scott Brown, Sophie (2017). The Histories of Raphael Samuel: A Portrait of a People's Historian. Canberra: Australian National University Press.

Sen, Dwaipayan (2012). Caste Politics and Partition in South Asian History. History Compass 1-12.

Sidhwa, Bapsi (1988). Ice Candy Man. London: Daunt Books.

Skinner, Quentin (1988). Language and Social Change. Meaning and Context: Quentin Skinner and his Critics (ed. James Tully). Princeton: Princeton University Press.

Thompson, Edward Palmer (1963). The Making of the English Working Class. London: Gollancz.

Thompson, Paul (2000) [1978]. The Voice of the Past ( $3^{\text {rd }}$ edn). New York: Oxford University Press.

Thompson, Paul, Bornat, Joanna (2017). The Voice of the Past, ( $4^{\text {th }}$ edn). New York: Oxford University Press.

Thomson, Alistair (2007). Four Paradigm Transformations in Oral History. The Oral History Review 34/1, 49-70.

White, Hayden (1980). The Value of Narrativity in the Representation of Reality. Critical Inquiry 7/1, 5-27.

Wilkomirski, Binjamin (1995). Bruchstücke: Aus einer Kindheit 1939-1948. Frankfurt a.M.: Jüdischer Verlag.

Yow, Valerie (1995). Ethics and Interpersonal Relationships in Oral History Research. The Oral History Review 22/1, 51-66.

Yow, Valerie (1997). "Do I like Them Too Much?": Effects of the Oral History Interview on the Interviewer and Vice-Versa. The Oral History Review 24/1: 55-79.

Yow, Valerie (2015). Recorded Oral History: A Guide for the Humanities and Social Sciences (3rd edn). Lanham, Maryland: Rowman and Littlefield.

Zachariah, Benjamin (2004). Nehru. London: Routledge.

Zachariah, Benjamin (2005). Developing India: An Intellectual and Social History, c. 1930-1950. Delhi: Oxford University Press.

Zachariah, Benjamin (2019). After the Last Post: The Lives of Indian Historiography. Berlin: De Gruyter Oldenbourg. 


\section{POVZETEK}

\section{ALI JE JEZIK MOČNEJŠI OD TISKANE BESEDE? RAZMIŠLJANJA O PRODUKCIJI USTNIH ZGODOVIN IN JEZIKIH LEGITIMITETE Benjamin ZACHARIAH}

Težave z ustnimi zgodovinskimi viri izčrpno opisujejo tako privrženci te prakse kot njeni nasprotniki in skeptiki. Kljub temu pa se vsi strinjajo, da ustne zgodovine odpirajo področja, kamor druge zgodovinske metode ne sežejo, jezik je namreč v mnogih pogledih fleksibilnejši od svinčnika oziroma tiska. Toda kako se pogovarjati brez artikuliranega izražanja v jeziku, ki sta ga vešča tako govorec kot poslušalec, spraševalec kot intervjuvanec? Kaj pa, kadar skupnega jezika sploh ni?

Članek v prvem delu prinaša nekaj razmišljanj o zadržanosti tradicionalnih zgodovinarjev v odnosu do ustnih zgodovinskih virov kot sredstva za obujanje dogodkov oziroma njihovega subjektivnega in čustvenega doživljanja, kakor tudi o njihovi zadržanosti do uporabe ustne zgodovine v komunikaciji, v kateri je vloga spraševalca pogosto podcenjena, čeprav bi potreba po samorefleksiji zahtevala prav nasprotno. Avtor navaja primere, v katerih ni ne jasno opredeljenega spraševalca ne intervjuvanca in v katerih intervjuvančeva doživetja niso zabeležena kot zgodba. Posledično se sprašuje o dometu ustnih zgodovinskih virov, kadar si komunikacija, v kateri nastajajo, prizadeva oživljati sicer nedostopne zgodbe in spomine, hkrati pa mora potekati v nekem skupnem jeziku, v katerem teh zgodb oziroma spominov ni mogoče jasno izraziti.

Avtor se je z navedeno tematiko začel resneje ukvarjati po vrsti debat, ki so sledile njegovemu nastopu v Ljubljani, kjer je govoril o možnostih in omejitvah ustnih zgodovinskih virov kot delu projekta z naslovom »Slovenske misijonarke v Indiji: Pozabljeno poglavje v medkulturnih odnosih«. Raziskava, ki se močno naslanja na ustne zgodovinske vire in - ker so prvotne pričevalke, razen ene, že pokojne - tudi na pričevanju druge generacije, je obravnavala življenjske zgodbe 12 slovenskih nun, ki so v 20. stoletju živele v Indiji. Težave z ubeseditvijo njihovih zgodb, ki jih obravnavajo tudi drugi članki v tej posebni številki revije, morajo vsekakor upoštevati dileme, ki jih poudarja pričujoči članek. 